\title{
Friends of the Court? Why EU governments file observations before the Court of Justice
}

\section{Journal Article}

\section{Author(s):}

Dederke, Julian (iD; Naurin, Daniel

Publication date:

2018-11

Permanent link:

https://doi.org/10.3929/ethz-b-000307416

Rights / license:

In Copyright - Non-Commercial Use Permitted

Originally published in:

European Journal of Political Research 57(4), https://doi.org/10.1111/1475-6765.12255 


\section{Friends of the Court?}

\section{Why EU governments file observations before the Court of Justice}

Julian Dederke* and Daniel Naurin**

* PhD candidate at Centre for Comparative and International Studies, ETH Zurich, julian.dederke@eup.gess.ethz.ch

** Professor of political science at PluriCourts, University of Oslo, and the Department of Political Science, University of Gothenburg, daniel.naurin@jus.uio.no

\section{Copyright}

This is the peer reviewed version of the following article: Dederke, J. \& Naurin, D. (2018). Friends of the Court? Why EU governments file observations before the Court of Justice. European Journal of Political Research 57(4): 867-882, which has been published in final form at $h t t p s: / / d o i . o r g / 10.1111 / 1475-6765.12255$. This article may be used for non-commercial purposes in accordance with Wiley Terms and Conditions for Use of Self-Archived Versions.

Funding

Financial support for Naurin's research and for gathering of some of the data used in this article was given by Riksbankens Jubileumsfond (RJ) and the Research Council of Norway through its Centres of Excellence funding scheme, project number 223274 (PluriCourts). 


\section{Abstract}

The preliminary reference procedure, under which the Court of Justice of the European Union (CJEU) responds to questions from national courts regarding the interpretation of EU law, is a key mechanism in many accounts of the development of European integration and law. While the significance of the procedure has been broadly acknowledged, one aspect has been largely omitted: The opportunity of member state governments to submit their views ('observations') to the Court in on-going cases. Previous research has shown that these observations matter for the Court's decisions, and thus that they are likely to have a significant impact on the course of European integration. Still, we know little about when and why member states decide to engage in the preliminary reference procedure by submitting observations. In this article, we show that there is significant variation, both between cases and between member states, in the number of observations filed. We develop a theoretical argument regarding how to explain this variation. Most importantly, we distinguish between legal and political reasons for governments to get involved in the preliminary reference cases, and argue that both types of factors should be relevant. By matching empirical data from inter-governmental negotiations on legislative acts in the Council of the EU, with member states' subsequent participation in the Court procedures, we are able to develop a research design to test these arguments. We find that the decision to submit observations can be tied both to concerns with the doctrinal development of EU law and to more immediate political preferences. We conclude that the legal (the CJEU) and political (the Council) arenas of the EU system are more interconnected than some of the previous literature would lead us to believe.

Keywords: judicial politics; courts; European Union; preliminary references; amicus briefs 


\section{Introduction}

The preliminary reference procedure plays an almost mythical role in theories of European legal integration. According to the neofunctionalist narrative, it was through this procedure that the Court of Justice (CJEU) was able to forge its ingenious alliance with lower-level national courts, which allowed the latter to enhance their status vis-à-vis domestic high courts, and the former to develop a de facto process of supranational judicial review of national law beyond the intentions of the EU member states (Weiler 1991, Burley and Mattli 1993, Alter 1998, Stone Sweet 2004, Hornuf and Voigt 2015). The thrust of the procedure is the following; a national court that is deciding on a case, which potentially involves European law, may request that the Luxembourg Court makes a ruling on the interpretation of the relevant European legal acts. The national court subsequently decides the case, with the help of the new guidance given by the CJEU. The legal purpose of the procedure is to ensure a uniform application of EU law in the various member states. In practice, the preliminary reference procedure has given an opportunity to individuals, social groups and companies all over Europe to challenge national law in their own national courts on the basis of European law, hoping that the national judges will ask their colleagues in Luxemburg for guidance and that the latter will find that EU law invalidates the unwanted national rules and regulations.

Most previous accounts of the preliminary reference procedure and its role in the development of European integration have treated it as a purely judicial affair. It has been seen to involve judges consulting with other judges about legal matters. An important part of the neofunctionalist story of legal integration is the idea of law as "mask and shield" (Burley and Mattli 1993: 72). The legal institutions have been protected from political interference by, on the one hand, the impenetrable nature of the language of law. The "technical' legal garb" has hidden the potentially salient implications of the Court's decisions, as these, "often require a lawyer's eye to discern" (Ibid). The strong norm of the rule of law in European democracies, on the other hand, has left little room for member state governments with regard to objecting to the decisions of their own national courts, following expansive interpretations of the CJEU (Alter 1998). As a consequence, European integration has occurred 
"within a domain shielded from the interplay of direct political interests" (Burley and Mattli 1993: 57).

Less acknowledged in the previous literature is the fact that the preliminary reference procedure also contains an opening for the member state governments to make their voices heard. Along with the parties to the case, and the European Commission, the member states have the right - within two months of the notification of the request from the national court - to submit a written observation stating their views with respect to the case at hand. ${ }^{1}$ While the significance of these observations for the outcomes of the procedures has been questioned by some scholars (Stein 1981, Stone Sweet and Brunell 2012), others have taken them more seriously (Mortelmans 1979, Granger 2004, Davies 2012, Carrubba and Gabel 2015, Larsson and Naurin 2016). For example, according to Carrubba and Gabel, the observations may be interpreted as implicit threats of non-compliance on behalf of the submitting member states, to which the Court is likely to respond by moderation in its decision-making (Carrubba and Gabel 2015). Furthermore, Larsson and Naurin conceive of the observations as informative signals to the Court regarding the likelihood that a legislative override may reverse the Court's decision should it take an activist stance (Larsson and Naurin 2016). Both these studies show evidence of a strong correlation between the direction of the observations and the decisions of the Court, also when controlling for other relevant factors. Besides these large- $\mathrm{N}$ studies, Davies has shown evidence of strong political awareness for (and support for) the Court's early ground-breaking decisions, and the perceived significance of the written observations, in his historical analysis of Germany's stand vis-à-vis European legal integration (Davies 2012). Furthermore, Rytter and Wind explain how in the case of Denmark, both the courts and the government have been reluctant to make use of the preliminary reference procedure, "primarily because referring a case to the ECJ may result in the setting aside of important national legislation" (Rytter and Wind 2011: 472). As a consequence, they argue, Denmark has put itself in the position of being a passive and powerless consumer-rather than a co-producer-of European law (Ibid: 470).

1 The Member States' right to submit observations is granted through article 23 of the Court's statute, which is annexed to the Treaties, Protocol (No 3) on the Statute of the Court of Justice of the European Union. 
The significance of the preliminary reference procedure has led scholars to study the propensity of national courts to file requests for preliminary rulings from the CJEU (Golub 1996, Wind et al. 2009, Wind 2010, Hübner 2015, Hübner 2016). However, despite the importance of the procedure, and the more recent questioning of its non-political nature, there is to date little systematic research on when and why member state governments decide to submit written observations to the CJEU. This is especially puzzling since there is substantial variation to be explained here. As we will show in the next section, the number of observations submitted vary strongly both between cases and between member states.

We develop a theoretical argument, and an empirical test, to address the question of when and why EU governments engage in the preliminary reference procedure by submitting written observations. We suggest that both legal and political considerations are likely to contribute to this decision. Clearly, the member state governments are fundamentally political actors, whose choices will be influenced by the national and party-political interests that they perceive to be at stake. We doubt that the technical language of law is able to mask in a systematic way how the Court's actions affect these interests, not least since the activist profile of the CJEU has been well known and debated for many years.

In our empirical analysis we find evidence that the EU governments take legal doctrine into account when submitting observations. At the same time, we also demonstrate that political preferences that were expressed during Council negotiations of the legislative acts that subsequently became the objects of the Court's interpretations, surface again in the member states decisions to submit observations to the CJEU. One implication of this study therefore is that the distinction between legal and political arenas and processes in the EU system should be treated as less sharp than much previous research would lead us to believe. EU governments are indeed able to keep two thoughts - law and politics - in mind at the same time. Importantly, the practice of submitting observations under the preliminary reference procedure contributes to the coherence of the legislative and judicial phases of the European integration process. 


\section{Observations in the preliminary reference procedure}

'Observations' is EU jargon for what is often known in other contexts as amicus curiae briefs, i.e. a submission from a 'friend of the court' who is not a party to the case, but still offers the Court information or advice regarding questions of law or fact. In the US system, scholars have since long observed how amicus curiae briefs were transformed "from neutral friendship to positive advocacy and partisanship" (Krislov 1963: 697, see also Collins 2008: 37-41). Although not formally parties to the case, the amici often have a clear interest in the outcome (Gleason and Provost 2016: 251). The literature on the scope and effects of amicus participation in the US is large (see, for example, Caldeira and Wright 1990; Songer and Sheehan 1993, Spriggs and Wahlbeck 1997, Collins 2008, Collins, Corley and Hamner 2015). Unsurprisingly, scholars have found that not all amici receive equal consideration by the US Supreme Court. Most successful are governmental actors, in particular the federal solicitor general and state attorneys general, i.e. the representatives of individual US states (Gleason and Provost 2016: 248). As a similar European literature is largely lacking, we will take some inspiration from the American literature when developing our theoretical argument and empirical analysis.

While the US Supreme Court is open to amicus curiae briefs from a wide range of societal groups, in the EU this opportunity is restricted (with a few exceptions) to the parties to the dispute, the European Commission and the member states. While the Commission makes full use of this privilege, and submits observations in all cases, the member states' records are much more varied. Usually, as seen in Figure 1, in the period we study here from 1997 until 2008, one to five member states submitted observations in the preliminary reference procedure. ${ }^{2}$ The average number of observations per case for the 1599 cases that we analyse is 3.6. In a substantial number of cases (467, or $29 \%$ ) only one member state - normally the state of the national court that requested the ruling - submitted an observation. However, in the high-profile case of Laval (C-341/05), for example, no less than 14 member states submitted observations.

\footnotetext{
${ }^{2}$ The data that we use is described in more detail in the research design section 
Figure 1. Number of member state observations per court case (1997-2008)

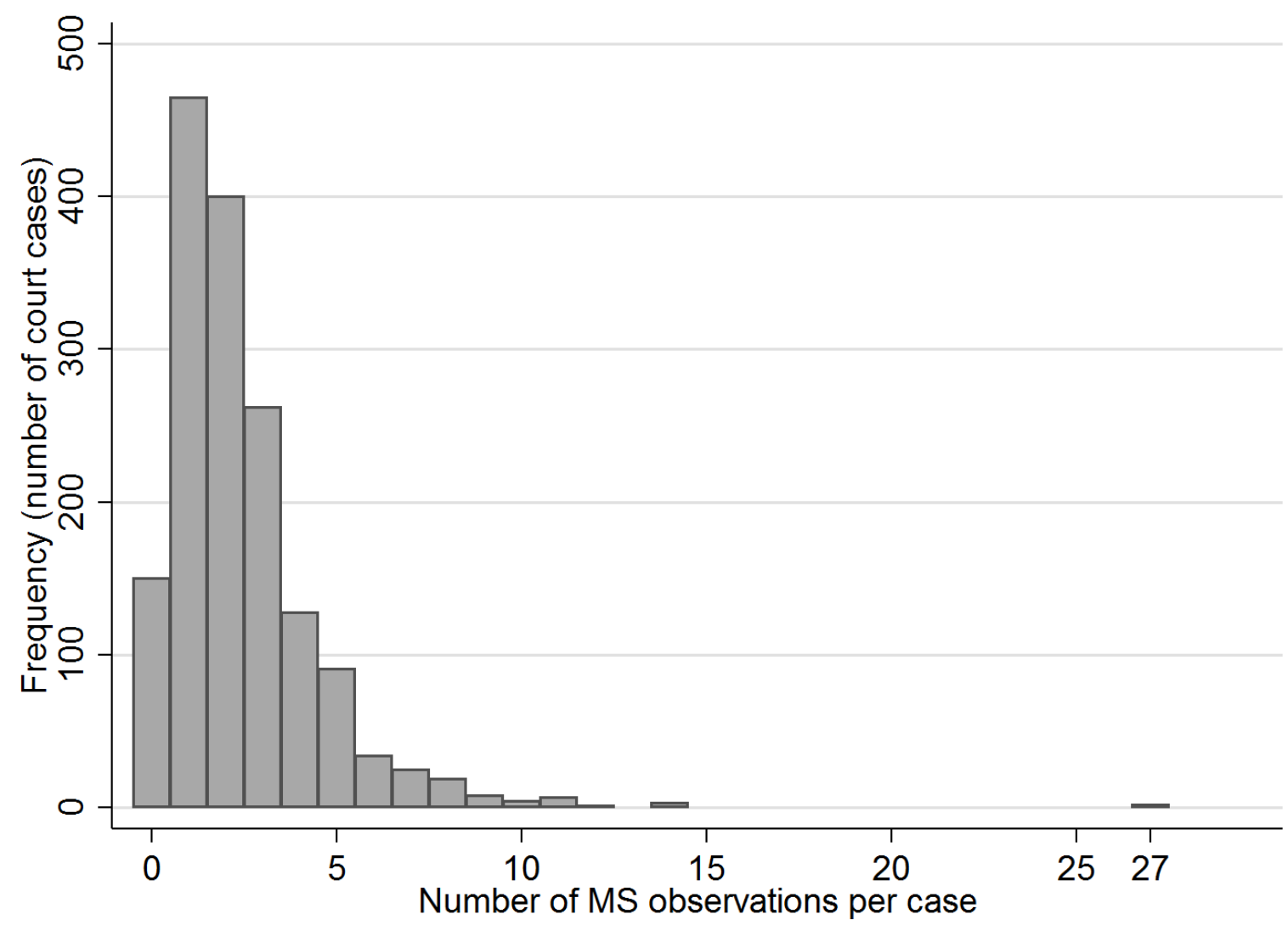

Furthermore, as seen in figure 2 , there is also substantial variation between member states. The bars indicate the total number of cases in which a member state submitted observations (measured on the left hand side). The line in the figure takes into account the fact that some member states became members of the EU only in 2004 or 2007. It shows the share of cases including an observation from a member state, relative to the number of cases raised by national courts during that member state's time as a member of the EU (measured on the right hand side). 
Figure 2. Frequency of case observations by member state (1997-2008)

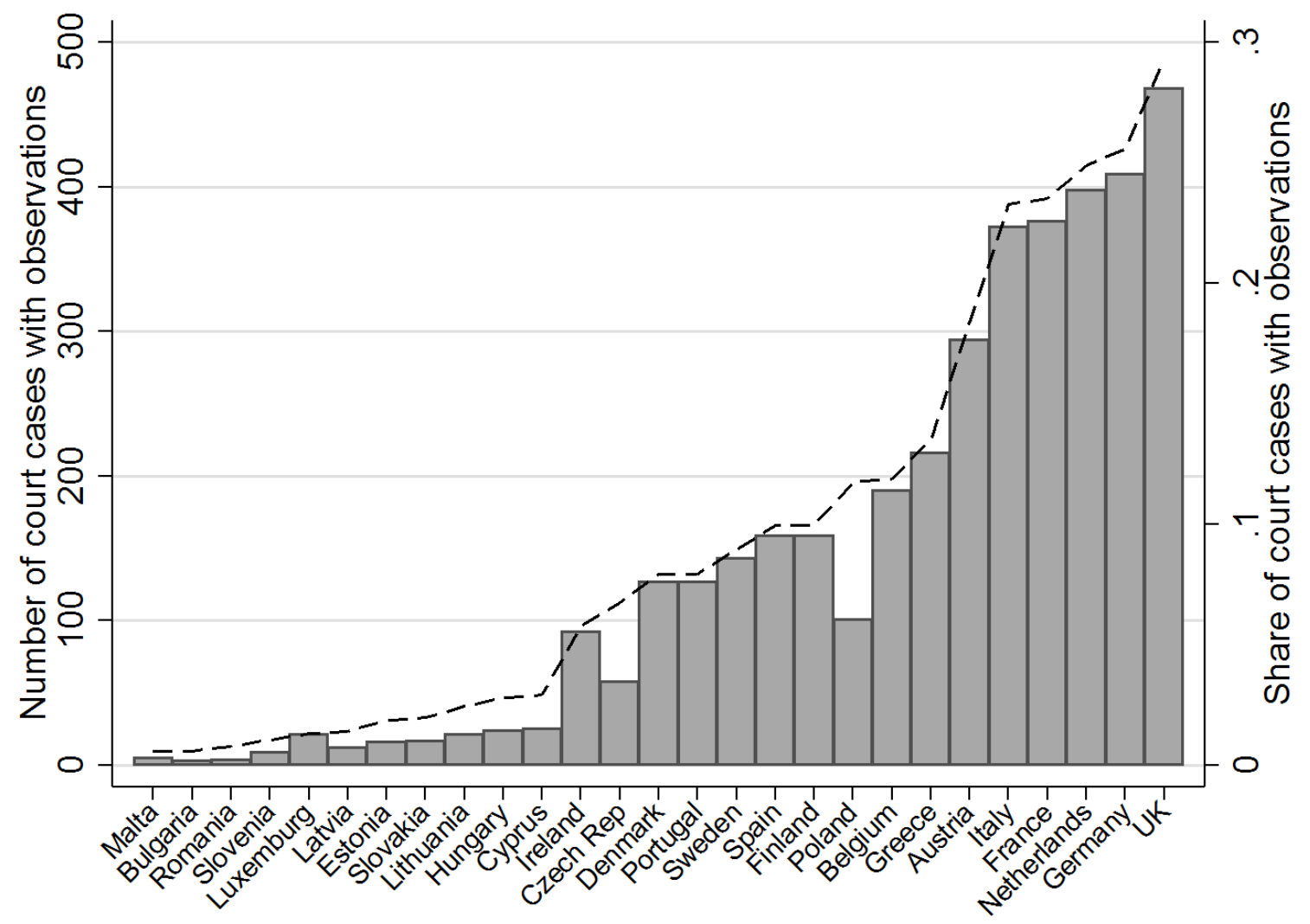

The UK was the most active member state during this period, with observations recorded in almost every third case. Germany, the Netherlands, France and Italy follow after the UK as more active participants in the procedure. Smaller and more recent member states, such as Malta, Bulgaria, Slovenia and Luxemburg, are found at the other end of the scale. These countries submit observations only in a fraction of the preliminary reference cases handled by the CJEU. Thus, size is clearly a factor that explains some of the variation between member states. This is likely to be an effect of larger states having more resources to allocate to legal staff in the ministries engaging in European affairs (Granger 2004: 23f). It is also an effect of the fact that more cases are raised in larger member states, and therefore more questions are referred by national courts from these countries. However, size is only one part of the story here, as seen from the differences between the relatively active mid-sized countries the Netherlands and Austria (filing observations in $25 \%$ and $18 \%$ of the cases respectively) and the relatively passive Portugal and Sweden (where observations were recorded in $8 \%$ and $9 \%$ of the cases respectively). 
What motivates member states to submit - or refrain from submitting - observations? Carrubba and Gabel interpret the observations as implicit threats of non-compliance (Carrubba and Gabel 2015) should the Court choose to decide against the wishes of the submitting member state, while Larsson and Naurin view them as signals of support (or resistance) of a possible legislative override (Larsson and Naurin 2016). However, neither of these scholars discuss why the member states would be inclined to send those signals in some cases but not in others, although implicitly political interests seem to be assumed. Alter has a somewhat more elaborated view of the member states' participation. According to her account of the legal integration process the member states have been lured by a time inconsistency problem, where they have focussed short-sightedly on the immediate materialpolitical effects of the Court's decisions while at the same time missing to take the longerterm doctrinal impact of these decisions into account. By making decisions containing, on the one hand, far-reaching doctrinal implications, and, on the other hand, acceptable immediate material effects in the views of the member states, the Court was able to incrementally strengthen the integrative power of EU law without provoking backlash from the member states (Alter 1998).

Looking at the American literature on amicus briefs, key to whether one decides to file a brief is the salience of the case. "When asked why they join amici briefs [...], state [attorney generals] ranked the importance of the issue ahead of everything else, even the probability of winning the case" (Provost 2011: 8, referring to Waltenburg and Swinford 1999). 'Case importance', 'political salience' and 'case salience' are used as predictors for amicus participation in these studies (Provost 2011, Zuber, Sommer and Parent 2015, Gleason and Provost 2016). In our view, the fact that salience is connected to action is common sense. More interesting is the question what it is that makes a case salient in the views of the amici. Again, in the literature on American states' amicus participation, it is assumed that the state representatives "have strong policy preferences and often seek to shape case law in line with their preferences" (Gleason and Provost 2016: 248. See also Waltenburg and Swinford 1999, Lemos and Quinn 2015). Thus, rather than concern about the coherence of legal doctrine, political policy preferences are expected to drive participation on behalf of the US states. 
It is reasonable to assume that policy preferences are central also to the behaviour of EU governments, even though the preliminary reference procedure in the EU system formally is a legal affair concerning the coherence of EU law. Are EU governments also likely to respond to legal salience, i.e. the development of a coherent precedent and legal doctrine? The idea of law as "mask and shield" (Burley and Mattli 1993), and the notion of member states as short-sighted policy defenders (Alter 1998), cast doubts that this is the case. However, we believe that an image of member states as ignorant and/or non-interested in legal affairs would underestimate both the political leadership and legal affairs units in most EU governments. The neofunctionalist writings in the 1990 s referred mainly to developments in the 1960s and 70s. Since then, European legal integration has developed far enough for most observers, whether political or legal actors, to realise the potentially profound implications of CJEU case law for public policy. Due to the massive increase in preliminary references over the last decades, the interactions between the Court and governments as amici have also become much more frequent. Furthermore, some EU governments have specific units monitoring cases that are handled by the CJEU (Van Stralen 2015). These offices are staffed with legal experts, with university degrees in EU law, who monitor the development of the CJEU's case law on behalf of their governments (Larsson et al. 2017).

In sum, despite the acknowledged significance of the preliminary reference procedure EU governments respond unevenly, with large variation in participation rates both between cases and between member states. Part of this variation is likely due to costs of monitoring and responding to complex legal issues, where in particular smaller member states need to prioritise their resources. But more importantly, the member state's participation in the preliminary reference procedure raises questions concerning the role of legal opinions and political preferences as predictors of behaviour, and regarding the distinction between legal and political arenas in the EU system. We expect that EU governments have a long-term interest in the development of EU law, and that their participation in the preliminary reference procedure may partly be explained by the legal significance of the cases raised. Many cases that reach the CJEU through the preliminary reference procedure are not of a high interest to EU lawyers. But, $(H 1)$ in those cases that have legal importance we expect to see more EU governments submitting observations. Moreover, given the formal right of member states to 
file observations, we find it unlikely that the preliminary reference procedure is a domain shielded from political interests. We do expect, therefore, to see $(\mathrm{H} 2)$ a connection between policy preferences of governments and the decision to submit observations. A challenge when addressing these research questions is how to define and operationalize the distinction between legal importance and political salience of a case. In the next section we will describe our research design in this respect, and the data we use to test our expectations.

\section{Research design}

How can we distinguish whether EU governments participate in the preliminary reference procedure mainly to promote their immediate policy preferences, and/or to respond to questions potentially affecting the broader development of European law? A case that is perceived as 'important', whether in the US or the EU system, normally has both a political and a legal dimension (Cook 1993). As Bailey and Maltzman point out, "statistically, [the] muddle of policy preferences and law creates an identification problem" (Bailey and Maltzman 2008: 1). Furthermore, most if not all of the alternative ways in which scholars have tried to measure case salience relies on data that were not available to the potential amici at the time. This is the case, for example, with respect to the most used case salience measure in the research on the US Supreme Court, which is based on media attention of the cases measured after the case was decided (Epstein and Segal 2000. See also Collins and Cooper 2016). Indices of legal salience are based on the content of the Court decision, such as whether the Court "either struck a law down as unconstitutional, or overturned or altered precedent" (Bailey, Kamoie and Maltzman 2015: 79. See also Collins 2008: 157). Another alternative that exists in the literature is using amicus briefs as a proxy for salience (Vining and Wilhelm 2011: 562), which is obviously less useful when the research question concerns the submission of those briefs.

In the EU literature scholars have used chamber size - the number of judges allocated to the case - as a proxy for salience (Carrubba, Gabel and Hankla 2008, Larsson and Naurin 2016, Larsson et al. 2017). In the CJEU, more important cases are decided in larger chambers. The Grand Chamber (normally consisting of 13 judges) is used for particularly significant or difficult 
cases, while other cases are delegated to chambers of (mostly) three and five judges. While this is a reasonable measure of salience in the eyes of the Court, it is less suitable in this context as the Court decides on the chamber only after it has received the observations from the member states. Chamber size therefore does not distinguish well between legal and political salience as perceived by the judges.

We have no perfect and final solution to the problem of measuring legal salience, and distinguishing it from political salience. In order to minimise the risk that our results are dependent on the choice of measure we apply two different indicators in our analyses. First, we follow Bailey and Maltzman's strategy in selecting a number of core legal doctrines to create a measure of legal salience reflecting doctrinal importance. The cases were coded with regards to whether they related to one of five important legal doctrines in EU law; direct effect, supremacy, state liability, loyal cooperation and non-discrimination. The variable Doctrine was coded (1) if the case was cited as relating to one of these doctrines in the standard textbook on EU Law, and (0) otherwise. ${ }^{3}$

Second, we follow Fowler et al. (2007) and Derlén and Lindholm (2014) in using the precedential authority of cases, as measured by network techniques applied to the citation network of the entire body of case law. The authority score of a case is based on the number of other cases citing it (indegree centrality), and the network centrality of these citing cases. Thus, a case that is often cited by other cases, and by cases that in turn are central to the citation network, receives a higher score. Cases with high authority "are important cases, saying something vital about the content or development of EU law" (Derlén and Lindholm 2014:684). The variable Authority uses the authority scores from Derlén and Lindholm, which were calculated on the basis of the entire caseload of 9,125 judgments made by the CJEU between 1954 and May 2011, including in total 38,278 citations of previous judgments (Derlén and Lindholm 2014). ${ }^{4}$

\footnotetext{
${ }^{3}$ We used EU Law: Text, Cases and Materials, by Craig and de Búrca, Oxford University Press. Both the fourth (2008) and the fifth (2011) editions were used. See Naurin et al. 2013 for details of the coding. 4 The values of the original Authority variable are very small relative to the other predictors (ranging from 0 up to 0.000675 ) and positively skewed. We therefore performed a log-transformation of the variable. Since zerovalues were represented, a constant (c=[lowest non-zero value]/2) was added to the original Authority values. 
It is difficult to know to what extent the member states were aware of the potential legal significance of the cases at the time the requests for preliminary references were filed in Luxemburg. Just as the alternative attempts of capturing legal significance, both Authority and Doctrine are measured ex post facto. Furthermore, whether a case actually becomes legally important is largely determined by the quality and innovativeness of the legal reasoning of the Court, which is a factor that is unknown before the ruling is handed down. Nevertheless, our analyses will indicate whether 1 ) cases that never received high authority scores, i.e. never became important sources of law, and 2) cases that were not considered important enough to be mentioned in the key textbook on EU law, are associated with lower levels of member state activity. If we find that this is the case, our interpretation will be that the member states have an ability to recognize legally significant cases, and a willingness to act when they do.

As already mentioned, previous research has often had difficulties distinguishing between legal and political salience of cases. One way of capturing the political importance of legal cases that has been used in studies of international courts is to identify particular subject matters as "politically sensitive", and then control for all cases that relate to that subject. For example, Voeten in his study of judicial behaviour in the European Court of Human Rights, treats cases relating to torture and inhumane treatment (Article 3 ) as especially politically sensitive (Voeten 2008: 421). Busch and Pelc use the same strategy when controlling for agriculture and health and safety standards in their research on legal conflicts in the WTO (Busch and Pelc 2010: 271). While this is certainly a reasonable strategy, it is also a bit crude in the sense that it assumes that all states find these subject matters equally sensitive.

Instead, we develop a measure of political salience that takes into account the individual variation regarding salience both between states and cases. For this purpose, we use the data by Thomson et al. (2012) who have collected data on the positions of EU governments during the negotiations in the Council of the EU. The data refers to 125 legislative proposals that were negotiated in the time period 1996 to 2008. By means of expert interviews, the researchers identified controversial issues within the legislative proposals, and the positions and salience of the member states with regard to these issues. Each legislative proposal included one or 
several such controversial issues. Most of the proposals led to a final legal act, while a few were suspended or rejected. The "salience or importance they attach to issues" was given by the experts as a score on a scale from 0 to 100, where 100 means that an issue was "of the highest importance" to a member state and 0 means that the issue is "of no importance whatsoever" (Thomson et al. 2012: 613). In our analysis, the variable Political Salience takes the mean value of the salience scores of the issues of each legislative proposal.

For example, one legislative proposal (COD/1998/325) subsequently resulted in the directive 2000/31/EC on electronic commerce. The proposal contained three controversial issues among the member states. One of these concerned the application of the country of origin principle vs. international private law to ecommerce contracts. A second issue concerned the inclusion of professional services in the directive, while the third issue related to the location liability for the content of websites. For the UK, the proposal was highly salient. The average salience value across the three issues was 83.3. The Netherlands, on the other hand, was only moderately interested in the proposal, and had a mean salience value of 16.7.

In order to create a dataset containing both the legal and political factors discussed here the data on policy salience of Thomson et al. (2012) was matched with the data set on preliminary references of Naurin et al. (2013). The latter data contains information on 1,599 preliminary reference procedures that were introduced during the time period 1997 to 2008. It contains the information that we need for the dependent variable of the study, i.e. whether written observations were submitted. The dependent variable MS Observation denotes whether a member state submitted an observation in the case at hand.

The data of Naurin et al. also records which legal acts that the case concerned, in the sense of being interpreted or referred to by the CJEU. ${ }^{5}$ In order to match the two datasets we used the Celex numbers of the legal acts that were produced from the legislative proposals negotiated in Thomson et al.'s data, to search the data from Naurin et al. for court cases where these legislative acts had played a role. Returning again to the directive on electronic commerce, we

\footnotetext{
${ }^{5}$ The coding is based on the "case affecting" heading in EUR-lex. 
find that this directive features in two of the preliminary reference cases in the time period up until 2008: C-275/06 Promusicae and C-236/08 Google France and Google. The Netherlands did not file any observation in these cases, while the UK did so in Promusicae but not in Google France. However, Promusicae also saw observations filed by Italy, Finland and Slovenia, all of which had varying salience levels in the Council negotiations.

In total, we were able to match 51 court cases in this way, of which each concerns at least one of the controversial legislative acts. ${ }^{6}$ The final matched dataset for the models including the variable Political Salience therefore amounts to 765 country-case units of analysis relating to the 15 member states that were members before the enlargement in $2004(51 * 15=765)$. Clearly, this is not a representative sample of either legislative acts or preliminary reference cases. All the 51 cases include political controversy at the legislative stage, and some degree of legal uncertainty leading to requests for preliminary references. Furthermore, the cases also refer to other legislative acts for which we lack information on salience, as these were not included in Thomson et al.'s data. ${ }^{7}$ There are of course alternative ways of measuring member states' preferences, such as manifesto data or expert survey data. The unique advantage of our approach, however, is that the data we use contains precise measures of governments' positions at the level of legislative proposals. Nevertheless, our analyses should be seen as a first attempt to study the link between individual member states' policy preferences in the legislative arena and their subsequent behaviour in the judicial arena in cases where the link should be possible to identify.

\footnotetext{
${ }^{6}$ Where a court case concerned several of the controversial acts, the average salience value of these acts for the particular member state was used.

7 In most cases (65\%) we have salience data on all legal acts cited by the Court. For the other cases, we lack salience values for one (18\%) or two (14\%) legal acts, while for two cases we lack salience values on more than two legal acts. When we compare the number of member states' observations in cases where we have all the data, to cases where we lack some data, we find that the latter tend to have fewer observations (13\% compared to $23 \%$ of the cases citing these laws contain observations). This is what we would expect given that 1) Thomson et al.'s data includes only legislative acts that were to some extent salient (measured by media attention) and 2) our hypothesis that political salience is connected to member state activity in the legal arena. Furthermore, for robustness we have run a simple model, including our measures of legal and political salience, on only those cases where we have all the data. We find that both variables have the expected effects also in this limited model with fewer observations.
} 
Another strategy that has been attempted as a proxy for political salience in previous research is to use the 'complexity' of the case. The logic would be that "as more legal areas are involved, a case becomes important to more observers [...]. Increased complexity therefore indicates the likelihood for greater policy consequences (or impact)" (Vining and Wilhelm 2011: 561). We find the use of legal complexity as a proxy for political salience problematic, not least since it fails to distinguish between political and legal salience. It is also possible to argue that member states may be less inclined to submit observations in more complex cases that require more resources and legal analysis. However, we will include complexity as a control variable in our analyses, although we do so without a clear expectation regarding the direction of the effect. The variable Complexity is calculated from a factor analysis of two variables: the number of questions the national court sent to the CJEU, and the number of affected issue areas (treaty chapters) involved in the case.

Resource constraints is a factor that needs to be taken into account (Granger, 2004: 23f; Gleason and Provost 2016: 259f). Van Stralen (2015) finds that this is indeed an issue that is perceived as important among Dutch and Swedish government officials representing their states in Luxemburg. As already seen in the descriptive data in the previous section, larger member states tend to be more active in the preliminary reference procedure. We therefore include a control for the economic size of the EU member states. The variable GDP takes the (logged) Gross Domestic Product from OECD (2016).

Before we turn to the empirical analyses we will note that one other factor also needs to be taken into account. The decision on whether or not to participate in a preliminary reference procedure by submitting an observation is strongly affected by whether the request for a preliminary ruling comes from one of the member state's own national courts, or whether it origins in another member state's court. In the 1,599 preliminary reference cases in the dataset by Naurin et al., member state governments submitted observations in 79 per cent of the cases where the referral came from one of their own courts. By contrast, in cases originating in other states' courts member states submitted observations in only 6 per cent of the cases. As we already noted, this is also likely to be one factor behind the clear difference between large and small states that we saw in Figure 2, as more court cases are likely to be 
raised in larger states. Member states are more likely to submit observations in cases originating from their own courts, both as a matter of principle and responsibility, as they are likely to have superior knowledge about relevant facts to the case compared to other governments. Furthermore, both the general awareness of the case, and the political and legal significance, is likely to be higher when the case directly concerns national policy and law. In the empirical analyses we will therefore distinguish between observations filed to cases that stem from a domestic court, and observations filed to cases that originated in another state. For robustness, we will use the variable Domestic Court, which takes the value of 1 if the case comes from the member state in question, and 0 otherwise, as a control variable. Table 1 shows the summary statistics of all the variables included in the analysis of the matched data.

Table 1. Summary statistics of variables in matched dataset

\begin{tabular}{lcccccc}
\hline \multicolumn{1}{c}{ Variable } & $N$ & Minimum & Maximum & Mean & $\begin{array}{c}\text { Std. } \\
\text { Deviation }\end{array}$ & Variance \\
\hline MS Observation (DV) & 765 & 0 & 1 & 0.193 & 0.395 & 0.156 \\
Authority & 765 & -10.702 & -7.268 & -9.022 & 0.755 & 0.570 \\
Doctrine & 765 & 0 & 1 & 0.216 & 0.412 & 0.169 \\
Political Salience & 765 & 0 & 97.5 & 54.880 & 21.839 & 476.955 \\
Domestic Court & 765 & 0 & 1 & 0.064 & 0.245 & 0.060 \\
Complexity & 765 & -1.377 & 3.412 & 0 & 1 & 1.001 \\
GDP & 765 & 3.212 & 8.057 & 6.180 & 1.188 & 1.411 \\
\hline
\end{tabular}

\section{Findings}

As we explained in the previous section the dependent variable MS observation is binary, noting whether a particular member state submitted an observation or not in the case at hand. Therefore, we use logistic regression models to analyse the data. Table 2 shows the results of four different regression models. The first two models investigate the effect of legal significance - as measured by the two variables Authority and Doctrine - across the whole dataset of Naurin et al. (2013). The unit of analysis is country-case for the 15 member 
states that were members of the EU over the whole time-period, which amounts to an $\mathrm{N}$ of $23955(1597 * 15)$.

Table 2. Logistic regression with robust standard errors: The effect of political and legal salience on the likelihood of member states submitting observations

\begin{tabular}{|c|c|c|c|c|}
\hline $\begin{array}{l}\text { DV: MSobservation } \\
(0 ; 1)\end{array}$ & $\begin{array}{l}\text { Model } 1 \\
\text { Odds Ratios }\end{array}$ & $\begin{array}{l}\text { Model } 2 \\
\text { Odds Ratios }\end{array}$ & $\begin{array}{l}\text { Model } 3 \\
\text { Odds Ratios }\end{array}$ & $\begin{array}{l}\text { Model } 4 \\
\text { Odds Ratios }\end{array}$ \\
\hline $\begin{array}{l}\text { Authority } \\
(-10.702--7.268)\end{array}$ & $\begin{array}{l}1.3568^{* * *} \\
(0.0356)\end{array}$ & & $\begin{array}{l}1.8915^{* * *} \\
(0.2912)\end{array}$ & \\
\hline $\begin{array}{l}\text { Doctrine } \\
(0 ; 1)\end{array}$ & & $\begin{array}{l}1.5747^{* * *} \\
(0.7172)\end{array}$ & & $\begin{array}{l}2.2968 * * \\
(0.5923)\end{array}$ \\
\hline $\begin{array}{l}\text { Political Salience } \\
(0-100)\end{array}$ & & & $\begin{array}{l}1.0090^{+} \\
(0.0049)\end{array}$ & $\begin{array}{l}1.0116 * \\
(0.0050)\end{array}$ \\
\hline $\begin{array}{l}\text { Domestic Court } \\
(0 ; 1)\end{array}$ & $\begin{array}{l}27.2089 * * * \\
(1.8765)\end{array}$ & $\begin{array}{l}26.7750^{* * *} \\
(1.8339)\end{array}$ & $\begin{array}{l}8.5807^{* * *} \\
(3.1684)\end{array}$ & $\begin{array}{l}8.3588^{* * *} \\
(2.8548)\end{array}$ \\
\hline $\begin{array}{l}\text { Complexity } \\
(-1.494-3.286)\end{array}$ & $\begin{array}{l}1.0680 * * \\
(0.0220)\end{array}$ & $\begin{array}{l}1.0988^{* * *} \\
(0.0226)\end{array}$ & $\begin{array}{l}0.6898^{* *} \\
(0.0836)\end{array}$ & $\begin{array}{l}0.7882^{*} \\
(0.0879)\end{array}$ \\
\hline $\begin{array}{l}\text { GDP } \\
(3.212-8.057)\end{array}$ & $\begin{array}{l}1.4993^{* * *} \\
(0.0260)\end{array}$ & $\begin{array}{l}1.4921^{* * *} \\
(0.0258)\end{array}$ & $\begin{array}{l}1.5370^{* * *} \\
(0.1462)\end{array}$ & $\begin{array}{l}1.4976^{* * *} \\
(0.1448)\end{array}$ \\
\hline Constant & $\begin{array}{l}0.1462^{* * *} \\
(0.0368)\end{array}$ & $\begin{array}{l}0.0086^{* * *} \\
(0.0010)\end{array}$ & $\begin{array}{l}2.2328 \\
(3.3430)\end{array}$ & $\begin{array}{l}0.0063^{* * *} \\
(0.0039)\end{array}$ \\
\hline Log likelihood & -7948.204 & -7975.930 & -321.464 & -325.325 \\
\hline Nagelkerke's $\mathrm{R}^{2}$ & 0.283 & 0.279 & 0.212 & 0.198 \\
\hline AIC & 15906.408 & 15961.860 & 654.927 & 662.651 \\
\hline $\mathrm{BIC}$ & 15946.828 & 16002.279 & 682.767 & 690.490 \\
\hline $\mathrm{N}$ & 23,955 & 23,955 & 765 & 765 \\
\hline
\end{tabular}

${ }^{\dagger} \mathrm{p}<0.10,{ }^{*} p<0.05,{ }^{* *} p<0.01,{ }^{* * *} p<0.001$. Odds ratios reported. Robust standard errors reported in parentheses.

We find that both our indicators of the legal significance of the case are associated with a higher tendency of member states' filing observations. Calculating the predicted probabilities based on the two models indicates that the effects are relatively substantive. The probability that a member state will file an observation in a case that does not concern legal doctrine is about 11 per cent $(0.105)$ according to model 2 , holding the other variables at their means. If the case does concern one of the legal doctrines - direct effect, supremacy, state liability, loyal cooperation or non-discrimination - the chances that a government submits an observation 
increases to 16 per cent $(0.156)$, i.e. an increase of almost 50 per cent from the case when none of these legal doctrines were involved. Comparing the minimal and maximum values of Authority from model 1 in a similar way shows an even larger increase in the predicted probabilities, from about 7 to about 18 per cent chance of seeing an observation filed.

The legal salience of the case thus clearly affects the propensity of member states making their voices heard in the preliminary reference procedure. Models three and four introduce our measure of political salience, as derived from member states' policy preferences at the stage of negotiating the legislation that the court is interpreting. As previously explained, these models have a much lower $\mathrm{N}$ as they are based on the 51 cases where the court is interpreting one of the legislative acts for which we have data on the salience of member states' preferences $(15 * 51=765)$.

We find that the effect of political salience is more uncertain than the variables measuring legal salience. In model 3, which includes Political Salience along with Authority and the control variables, the effect of Political Salience is associated with a p-value of 0.066 . In model 4, where legal significance instead is measured by Legal Doctrine, the effect is slightly more certain ( $p=0.019)$. Substantively, the effects are non-trivial. Based on model 3 , we find that a state that did not indicate much of an interest in the controversial issues during the negotiations of the legislative act (Political Salience $=0$ ) has a probability of submitting an observation of about 10 per cent. The chances more than double if the state had a strong preference in the Council negotiations (Political Salience $=100$ ), when the probability of submitting an observation is 22 per cent. In model 4 , the effect is even stronger, with the probability increasing from 9.5 per cent up to 25 per cent.

Importantly, as models three and four also include the two variables that we use to capture legal significance, which are both highly significant, the effects of salient policy preferences that we find are added to the legal aspects, rather than subsumed by these. Thus, although the legal and political aspects of a case may be difficult to disentangle our results indicate that to fully understand governments' behaviour both aspects need to be taken into account. 
Finally, we note that the control variables that were included turned out to be significant in all the models. The large and significant effects of GDP and Domestic Court were highly expected, given the descriptive data that we showed previously. In particular, a member state is much more likely to submit an observation if the request for a preliminary reference comes from one of its own courts. This is natural, as the member states' own legislation is more directly at stake in these cases, even though the interpretations made by the CJEU formally affects all member states. Somewhat puzzling is that the effect of Complexity shifts from positive in the larger sample of cases in models one and two, to negative in the smaller sample in models three and four. ${ }^{8}$

\section{Conclusions}

The preliminary reference procedure has been recognized as a key mechanism in the development of European legal integration. So far, however, it has been conceived mainly as a judicial affair, providing the opportunity for the alliance between the CJEU and lower-level national courts to 'mask and shield' the advances of European law (Burley and Mattli 1993). The member states' role in the procedure has been largely omitted, even though a few studies have found that their observations have a significant impact on the Court's decisions (Carrubba and Gabel 2008, Larsson and Naurin 2016). This article has provided the first systematic large-scale analysis of the member states' propensity to engage in the procedure by submitting written observations, thereby potentially influencing the development of EU law.

We have found that participation in the preliminary reference procedure is an uneven phenomenon, both across states and cases. While most states file briefs when their own legislation is directly at stake, it is significantly less common to take a broader European perspective in the sense of engaging in cases that have their origin in other states. The fact that more cases are raised in larger member states partly explains why these states file more observations, but we also found that economic size has an independent positive effect over

\footnotetext{
${ }^{8}$ A closer look at the distribution of complexity in the two samples demonstrates that cases of higher complexity are less common in the smaller sample, which may contribute to the difference.
} 
and above case origin. More resources available for monitoring case law and conducting legal analysis is probably of importance in this respect. Overall, and with a few exceptions (Austria and the Netherlands in particular) participation in the preliminary reference procedure is dominated by larger states.

Our study also suggests that member states participate in the process both with an eye to influencing the broader development of European law, and with the purpose of defending more immediate policy preferences. Cases that are potentially more important in terms of their effect on legal doctrine and their status as sources of case law (Authority) tend to trigger more member state observations. This indicates that the purported 'mask of law' may not be as impenetrable to EU governments as previous research has suggested (Cf. Larsson et al. 2017).

In this regard, our study complements and deepens the ongoing reinterpretation of the larger narrative of European legal integration as an opaque and unintended development from the perspective of the member states, driven mainly by courts, lawyers and litigants. Besides the political science work in more recent years, emphasising the sensitivity of the CJEU to member states' preferences (Carrubba and Gabel 2008, Martinsen 2015, Larsson and Naurin 2016), legal historians have found the constitutionalization of the treaties a more contentious and politicized process than previously assumed (Davies 2012, Davies and Rasmussen 2012). Building on the previous work of Granger (2004) and Rytter and Wind (2011), our study provides further nuance and precision to the role of member states in the preliminary ruling procedure.

We find that member states are able to keep both law and politics in mind at the same time, when deciding whether to engage in the preliminary reference procedure. The fact that we were able to trace member states' preferences during the legislative phase to their participation in subsequent court cases demonstrates that there is a link between the formally separate institutional arenas. In this respect, the practice of filing observations contributes to coherence in the ongoing judicial-political dialogue that determines the development of EU law. 


\section{References}

Alter, Karen J. 1998. Who Are the "Masters of the Treaty"?: European Governments and the European Court of Justice. International Organization 52(1): 121-147.

Bailey, Michael A., Brian Kamoie, and Forrest Maltzman. 2005. Signals from the Tenth Justice: The Political Role of the Solicitor General in Supreme Court Decision Making. American Journal of Political Science 49(1): 72-85.

Bailey, Michael A. and Forrest Maltzman. 2008. Does Legal Doctrine Matter?: Unpacking Law and Policy Preferences on the U.S. Supreme Court. American Political Science Review 102(3): 369-384.

Busch, Marc L. and Krzysztof J. Pelc. 2010. The Politics of Judicial Economy at the World Trade Organization. International Organization 64(2): 257-279.

Burley, Anne-Marie and Walter Mattli. 1993. Europe before the Court: A political theory of legal integration. International Organization 47(1): 41-76.

Caldeira, Gregory A. and John R. Wright. 1990. Amici Curiae before the Supreme Court: Who Participates, When, and How Much? The Journal of Politics 52(3): 782-806.

Carrubba, Clifford J., Matthew Gabel, and Charles Hankla. 2008. Judicial Behavior under Political Constraints: Evidence from the European Court of Justice. American Political Science Review 102(4): 435-452.

Carrubba, Clifford J. and Matthew J. Gabel. 2015. International courts and the performance of international agreements: A general theory with evidence from the European Union. New York, NY: Cambridge University Press.

Collins, Paul M. 2008. Friends of the Supreme Court. Oxford: Oxford University Press. 
Collins, Paul M., Pamela C. Corley, and Jesse Hamner. 2015. The Influence of Amicus Curiae Briefs on U.S. Supreme Court Opinion Content. Law \& Society Review 49(4): 917-944.

Collins, T.A. \& Cooper, C.A. (2016). The Case Salience Index, Public Opinion, and Decision Making on the U.S. Supreme Court. Justice System Journal 37(3): 232-45.

Cook, Beverly B. 1993. Measuring the Significance of U.S. Supreme Court Decisions. The Journal of Politics 55(4): 1127-1139.

Craig, Paul and Gráinne de Búrca. 2011. EU Law: Text, Cases, and Materials. Oxford, New York: Oxford University Press.

Davies, Bill. 2012. Resisting the European Court of Justice: West Germany's Confrontation with European Law, 1949-1979. Cambridge: Cambridge University Press.

Davies, Bill and Morten Rasmussen. 2012. Towards a New History of European Law. Contemporary European History 21(3): 305-318.

Derlén, Mattias and Johan Lindholm. 2014. Goodbye van Gend en Loos, Hello Bosman ?: Using Network Analysis to Measure the Importance of Individual CJEU Judgments. European Law Journal 20(5): 667-687.

Epstein, L. \& Segal, J.A. (2000). Measuring Issue Salience. American Journal of Political Science 44(1): 66-83.

Fowler, James H., Timothy R. Johnson, James F. Spriggs, Sangick Jeon, and Paul J. Wahlbeck (2007). Network Analysis and the Law. Measuring the Legal Importance of Precedents at the U.S. Supreme Court. Political Analysis 15(3): 324-46. 
Gleason, Shane A. and Colin Provost. 2016. Representing the States Before the U.S. Supreme Court: State Amicus Brief Participation, the Policy-making Environment, and the Fourth Amendment. Publius: The Journal of Federalism 46(2): 248-273.

Golub, Jonathan. 1996. The politics of judicial discretion: Rethinking the interaction between national courts and the European Court of Justice. West European Politics 19(2): 360-385.

Granger, Marie-Pierre F. 2004. When governments go to Luxembourg...: the influence of governments on the Court of Justice. European Law Review 29(1): 3-31.

Hornuf, Lars and Stefan Voigt. 2015. Analyzing preliminary references as the powerbase of the European Court of Justice. European Journal of Law and Economics 39(2): 287-311.

Hübner, Denise C. 2015. The content of EU directives and their judicial enforcement through member state courts in the EU fifteen. Dissertation. Dublin: University of Dublin.

Hübner, Denise C. 2016. The 'National Decisions' database (Dec.Nat): Introducing a database on national courts interactions with European Law. European Union Politics 17(2): 324-339.

Krislov, Samuel. 1963. The Amicus Curiae Brief: From Friendship to Advocacy. The Yale Law Journal 72(4): 694.

Larsson, Olof and Daniel Naurin. 2016. Judicial Independence and Political Uncertainty: How the Risk of Override Affects the Court of Justice of the EU. International Organization 70(2): 377-408.

Larsson, Olof, Daniel Naurin, Mattias Derlén and Johan Lindholm. 2017. Speaking Law To Power. The Strategic Use of Precedent of the Court of Justice of the European Union", Comparative Political Studies 50(7): 879-907. 
Lemos, Margaret H. and Kevin M. Quinn. 2015. Litigating State Interests: Attorneys General as Amici. New York University Law Review 90: 1229-1268.

Mortelmans, K. J. M. 1979. Observations in the Cases governed by Article 177 of the EEC Treaty: Procedure and Practice. Common Market Law Review 16(4): 557-590.

Naurin, Daniel, Per Cramér, Olof Larsson, Sara Lyons, Andreas Moberg, and Allison Östlund. 2013. Coding observations of the Member States and judgments of the Court of Justice of the EU under the preliminary reference procedure 1997-2008: Data report. CERGU'S Working Paper Series 1: Centre for European Research (CERGU) University of Gothenburg.

OECD. 2016. Gross domestic product (GDP) (indicator). doi: 10.1787/dc2f7aec-en (Accessed on 08 May 2016).

Provost, Colin. 2011. When to Befriend the Court?: Examining State Amici Curiae Participation Before the U.S. Supreme Court. State Politics \& Policy Quarterly 11(1): 4-27.

Rytter, Jens Elo and Marlene Wind. 2011. In need of juristocracy? The silence of Denmark in the development of European legal norms. International journal of constitutional law 9(2): 470-504.

Songer, Donald R. and Reginald S. Sheehan. 1993. Interest Group Success in the Courts: Amicus Participation in the Supreme Court. Political Research Quarterly 46(2): 339-354.

Spriggs, James F. and Paul J. Wahlbeck. 1997. Amicus Curiae and the Role of Information at the Supreme Court. Political Research Quarterly 50(2): 365-386.

Stein, Eric. 1981. Lawyers, Judges, and the Making of a Transnational Constitution. The American Journal of International Law 75(1): 1-27. 
Stone Sweet, Alec. 2004. The Judicial Construction of Europe. Oxford: Oxford University Press.

Stone Sweet, Alec and Thomas Brunell. 2012. The European Court of Justice, State Noncompliance, and the Politics of Override. American Political Science Review 106(1): 204213.

Thomson, Robert, Javier Arregui, Dirk Leuffen, Rory Costello, James Cross, Robin Hertz, and Thomas Jensen. 2012. A new dataset on decision-making in the European Union before and after the 2004 and 2007 enlargements (DEUII). Journal of European Public Policy 19(4): 604622.

van Stralen, Floris. 2015. The Member States and the Court of Justice. Why do Member States participate in preliminary reference proceedings? Master Thesis. Gothenburg: University of Gothenburg.

Vining, Richard L. and Teena Wilhelm. 2011. Measuring Case Salience in State Courts of Last Resort. Political Research Quarterly 64(3): 559-572.

Voeten, Erik. 2008. The Impartiality of International Judges: Evidence from the European Court of Human Rights. American Political Science Review 102(4): 417-433.

Waltenburg, Eric N. and Bill Swinford. 1999. Litigating Federalism: The States Before the U.S. Supreme Court. Westport, London: Greenwood Publishing Group.

Weiler, Joseph H. H. 1991. The Transformation of Europe. The Yale Law Journal 100(8): $2403-2483$.

Wind, Marlene, Dorte Sindbjerg Martinsen, and Gabriel Pons Rotger. 2009. The Uneven Legal Push for Europe: Questioning Variation when National Courts go to Europe. European Union Politics 10(1): 63-88. 
Wind, Marlene. 2010. The Nordics, the EU and the Reluctance Towards Supranational Judicial Review. JCMS: Journal of Common Market Studies 48(4): 1039-1063.

Zuber, Katie, Udi Sommer, and Jonathan Parent. 2015. Setting the Agenda of the United States Supreme Court?: Organized Interests and the Decision to File an Amicus Curiae Brief at Cert. Justice System Journal 36(2): 119-137. 